\title{
Neurophysiological Endophenotypes, CNS Disinhibition, and Risk for Alcohol Dependence and Related Disorders
}

\author{
Bernice Porjesz* and Madhavi Rangaswamy \\ Henri Begleiter Neurodynamics Laboratory, SUNY Downstate Medical Center, \\ Brooklyn, New York \\ E-mail: bp@cns.hscbklyn.edu; Bernice.porjesz@Downstate.edu
}

Received June 18, 2007; Accepted July 11, 2007; Published November 2, 2007

Biological endophenotypes are more proximal to gene function than psychiatric diagnosis, providing a powerful strategy in searching for genes in psychiatric disorders. These intermediate phenotypes identify both affected and unaffected members of an affected family, including offspring at risk, providing a more direct connection with underlying biological vulnerability. The Collaborative Study on the Genetics of Alcoholism (COGA) has employed heritable neurophysiological features (i.e., brain oscillations) as endophenotypes, making it possible to identify susceptibility genes that may be difficult to detect with diagnosis alone. We found significant linkage and association between brain oscillations and genes involved with inhibitory neural networks (e.g., GABRA2, CHRM2), including frontal networks that are deficient in individuals with alcohol dependence, impulsivity, and related disinhibitory disorders. We reported significant linkage and linkage disequilibrium for the beta frequency of the EEG and GABRA2, a $\mathrm{GABA}_{\mathrm{A}}$ receptor gene on chromosome 4, which we found is also associated with diagnosis of alcohol dependence and related disorders. More recently, we found significant linkage and association with GABRA2 and interhemispheric theta coherence. We also reported significant linkage and linkage disequilibrium between the theta and delta event-related oscillations underlying P3 to target stimuli and CHRM2, a cholinergic muscarinic receptor gene on chromosome 7 , which we found is also associated with diagnosis of alcohol dependence and related disorders. Thus, the identification of genes important for the expression of the endophenotypes (brain oscillations) helps when identifying genes that increase the susceptibility for risk of alcohol dependence and related disorders. These findings underscore the utility of quantitative neurophysiological endophenotypes in the study of the genetics of complex disorders. We will present our recent genetic findings related to brain oscillations and Central Nervous System (CNS) disinhibition.

KEYWORDS: endophenotypes, EEG, event-related potentials

Alcoholism is a common, complex (non-Mendelian) disorder with contributions from both genetic and environmental influences and their interactions. As psychiatric diagnosis is dichotomous (an individual is 
either affected or unaffected), it is difficult to use diagnosis as the sole phenotype when studying the genetics of complex disorders, such as alcoholism. It has been suggested that, ideally, molecular genetic studies should not be performed on psychiatric diagnoses alone, which reflect distal and variable effects of genes, but on quantitative neurobiological measures or markers that reflect more proximal effects of genes involved in the genetic predisposition for developing psychiatric disorders[1]. These quantitative biological markers (endophenotypes or intermediate phenotypes) serve as covariates that correlate with the main trait of interest (diagnosis) and serve to better define that trait or its underlying genetic mechanism[2,3,4]. The advantages of using quantitative neurobiological measures of risk as endophenotypes in the search for genes involved in complex disorders are that they are closer to gene action involved in the predisposition for the disorder, they are genetically simpler than clinical endpoints, and quantitative traits provide more power to localize and characterize disease susceptibility genes[5].

Recent evidence suggests that alcohol dependence is part of a spectrum of disinhibitory disorders, which include externalizing and substance use disorders. Many of the same genetic risk factors underlie these disinhibitory co-occurring disorders and can be explained by a small number of common underlying genetic factors[6]. Genetic studies of neuroelectric endophenotypes (brain oscillations, such as EEG and event-related potentials [ERPs], including the P3 component) provide a powerful strategy for identifying underlying susceptibility genes for developing these disinhibitory disorders.

\section{BRAIN OSCILLATIONS AS ENDOPHENOTYPES}

Brain oscillations provide a rich source of potentially useful endophenotypes for psychiatric genetics, as they represent important correlates of human information processing and are associated with fundamental processes of perception to cognition. These oscillations are dynamic indices of the millisecond-bymillisecond balance between excitation and inhibition in brain neural networks. Brain oscillations reflect ensembles of neurons firing in synchrony and represent the basic mechanism of neural communication. High-frequency (beta, 12-28 Hz; gamma, 28+ Hz) synchronizations are involved in short-range communication, while low frequencies (delta, 1-3 Hz; theta, 4-7 Hz; alpha, 8-12 Hz) are involved in longer-range communication between brain areas[7]. Brain oscillations represent important correlates of human information processing and cognition. They represent traits less complex and more proximal to gene function than either diagnostic labels or traditional cognitive measures. Therefore, these oscillations may be utilized as phenotypes of cognition, and as valuable tools for the understanding of some complex genetic disorders. It should be noted that brain oscillations meet criteria for endophenotypes and are highly heritable: delta $76 \%$, theta $89 \%$, alpha $89 \%$, beta $86 \%[8]$.

In the Collaborative Study on the Genetics of Alcoholism (COGA), we have successfully used brain oscillations as endophenotypes in the search for genes involved in alcohol dependence and related disorders. We have focused on resting eyes-closed EEG, as well as oscillations recorded during sensory and cognitive tasks (ERPs) that differentiate between alcoholics and controls, and between high-risk offspring and controls.

\section{RESTING EEG BETA POWER: GABRA2 GENE}

Increased beta power in the resting EEG of alcoholics has been well documented[9,10,11,12,13]. Several studies also report increased resting beta power in offspring of alcoholics[14,15,16], and it has been reported at frontal leads in those who also have a diagnosis of antisocial personality disorder (ASP)[17]. Increased resting beta power has also been reported in a large sample of offspring of alcoholics at high risk from the COGA project[16]. As it is already observed in offspring before the onset of alcohol dependence, this increased beta antecedes the development of alcoholism and is considered to be a trait rather than a state measure. 
Significant linkage and linkage disequilibrium between the EEG beta frequency and a $\mathrm{GABA}_{\mathrm{A}}$ receptor gene on chromosome 4 has been reported by COGA[18] (Fig. 1). Subsequent SNP (single nucleotide polymorphism) analysis in COGA indicated that the same GABRA2 gene associated with the EEG beta endophenotype is associated with DSM-IV diagnosis of alcohol dependence[19], substance dependence[20], ASP[21], and childhood conduct disorder[22]. The association between GABRA2 and alcohol dependence has been replicated by a number of groups throughout the world[23,24,25,26].

\section{Linkage of Beta Frequencies}

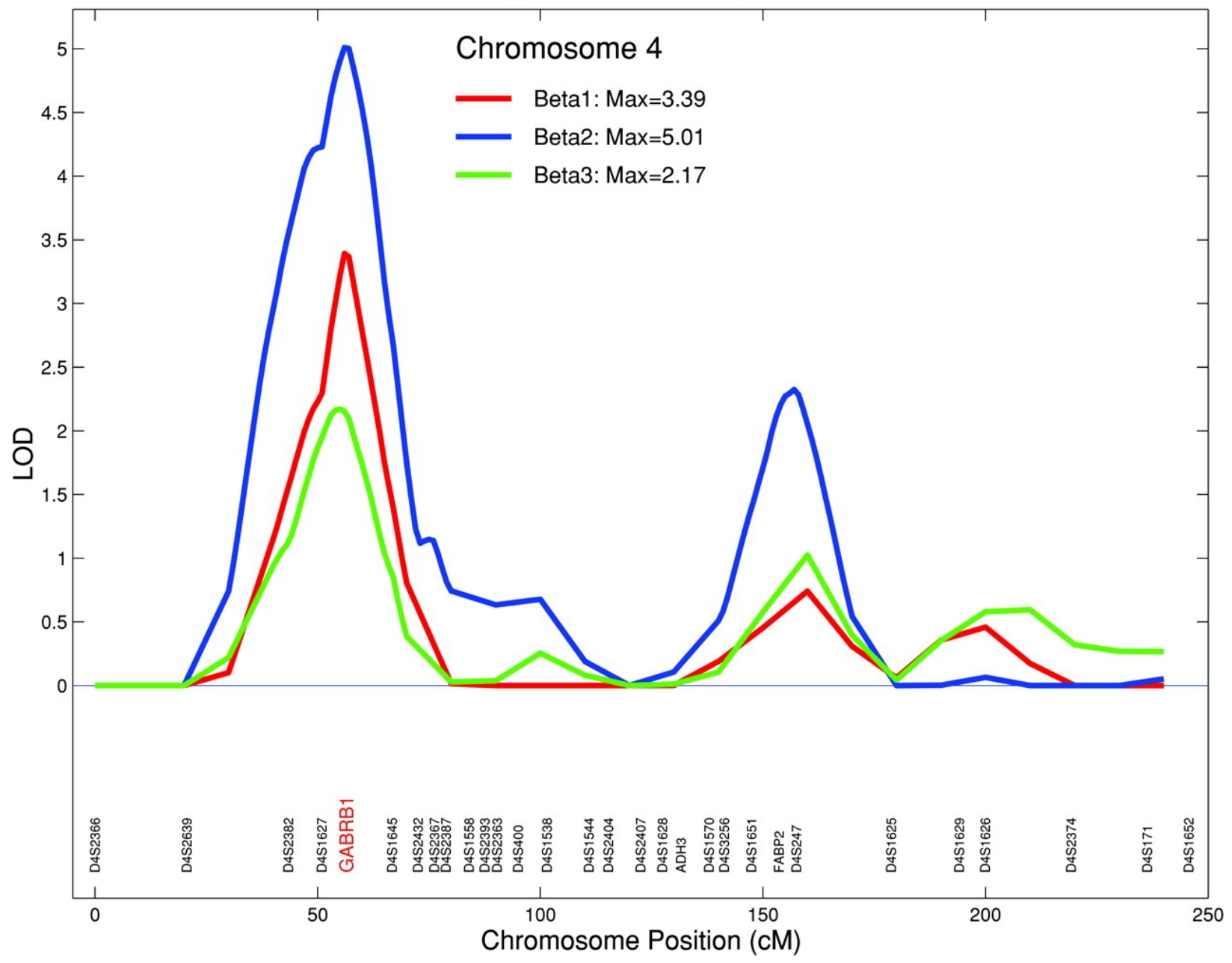

FIGURE 1. Linkage results of resting EEG beta band power for beta $1(12.5-16 \mathrm{~Hz})$, beta $2(16.5-20 \mathrm{~Hz})$, and beta $3(20.5-28 \mathrm{~Hz})$ on chromosome 4 at a cluster of $\mathrm{GABA}_{\mathrm{A}}$ receptor genes. $(\mathrm{N}=1553$ individuals from 250 families.)

One of the important mechanisms of the beta rhythm generation is based on properties of inhibitory circuits, and the balance between networks of excitatory pyramidal cells and inhibitory interneurons that involve $\mathrm{GABA}_{\mathrm{A}}$ action as the pacemakers[27]. This suggests that variations in the GABRA2 gene affect the inhibitory tone and, thus, affect the level of neural excitability, which in turn affects the predisposition to develop alcohol dependence and related disorders. As alcoholics and offspring at high risk manifest increased beta activity, this indicates an imbalance between excitation-inhibition (CNS disinhibition). This provides a biological hypothesis relating the underlying CNS disinhibition to the genetic risk for alcohol dependence and related disorders[28]. The involvement of the GABAergic system in alcoholism 
is supported by neuroimaging studies, which report specific deficits in GABA benzodiazepine receptors in the brains of alcoholics[29,30,31] and individuals at risk[32]. Taken together, these findings suggest GABA deficits in the brains of alcoholics, and individuals at risk may account for their lack of CNS inhibition (hyperexcitability) and may be involved in the predisposition to develop alcoholism.

\section{INTERHEMISPHERIC THETA COHERENCE: GABRA2 AND CHRM2 GENES}

Another EEG measure that was examined by COGA is EEG coherence, a measure of cortical synchronization in neural networks, indexing communication in populations of neurons. Recent studies have implicated involvement of thalamocortical circuitry in the theta frequency coherence[33]. We recently observed that alcoholics in the resting state have higher coherence in most frequency bands overall when compared to age-matched controls. Alcoholics manifest significant increases in resting EEG interhemispheric high theta $(6-7 \mathrm{~Hz})$ coherence, particularly posteriorly at parietal-occipital and centroparietal regions[34]. This increased coherence observed in alcoholics is indicative of altered thalamo- and cortico-cortical functional connectivity.

Highly significant linkage was found in COGA on chromosome 4 for the same GABRA2 gene and high theta coherence at parietal-occipital leads[35] (Fig. 2). Family-based association analyses with the cluster of $\mathrm{GABA}_{\mathrm{A}}$ receptor genes under this linkage peak revealed strong association with a large number of SNPs (several at $p<0.001$ ) genotyped in GABRA2 for the Caucasian-only subset. There was no significant association with other genes in the $\mathrm{GABA}_{\mathrm{A}}$ cluster on chromosome 4 . These results suggest that GABRA2 might influence susceptibility to alcohol and drug dependence not just by modulating level of neural excitation, but also by influencing functional connectivity of interhemispheric networks.

In addition, significant linkage and association for the interhemispheric high theta coherence centroparietal phenotype was found with a muscarinic acetylcholine receptor (M2) gene (CHRM2) on chromosome 7. Significant linkage and association for evoked theta band responses at the same CHRM2 gene have been previously reported[36,37] (see below).

Both the GABAergic and cholinergic systems interact significantly in the functions of local inhibitory circuits, thus affecting network functions. Increased strength of GABAergic inhibition has been reported to be a likely mechanism underlying the impaired synaptic plasticity observed with M2 knockout mice. These mice demonstrate impaired behavioral flexibility and memory deficits[38]. In a recent study examining muscarinic control of long-range cortical GABAergic inhibition, the authors suggested that M2 receptor activation produces a presynaptic inhibition of GABA release by long-range inhibitory neurons of the perirhinal cortex projecting to the entorhinal cortex[39]. These networks have been shown to be highly relevant to memory-related processes.

\section{THETA AND DELTA EVENT-RELATED OSCILLATIONS UNDERLYING P3: CHRM2 AND GRM8 GENES}

The P3 component has repeatedly been reported to be reduced in alcoholics and in offspring at high risk[40,41], providing a good phenotype for genetic studies. Linkage studies have been performed on P3 amplitude[41]. However, the P3 component is not a unitary phenomenon, but emanates from multiple sources in the brain with contributions from frontal cortex (including anterior cingulate) and hippocampus[42,43,44,45]. Several studies have demonstrated that P3 responses are primarily the outcome of theta $(4-7 \mathrm{~Hz})$ and delta $(1-3 \mathrm{~Hz})$ oscillations elicited during cognitive processing of stimuli[46,47,48,49,50,51], with delta oscillations more concentrated in the posterior region, while theta is more centered in the fronto-central region[50]; theta oscillations also contribute strongly to N2 components. Reciprocal synchronization has been observed in the theta range between hippocampus and frontal and parietal regions in the brain during attentional tasks[7]. 


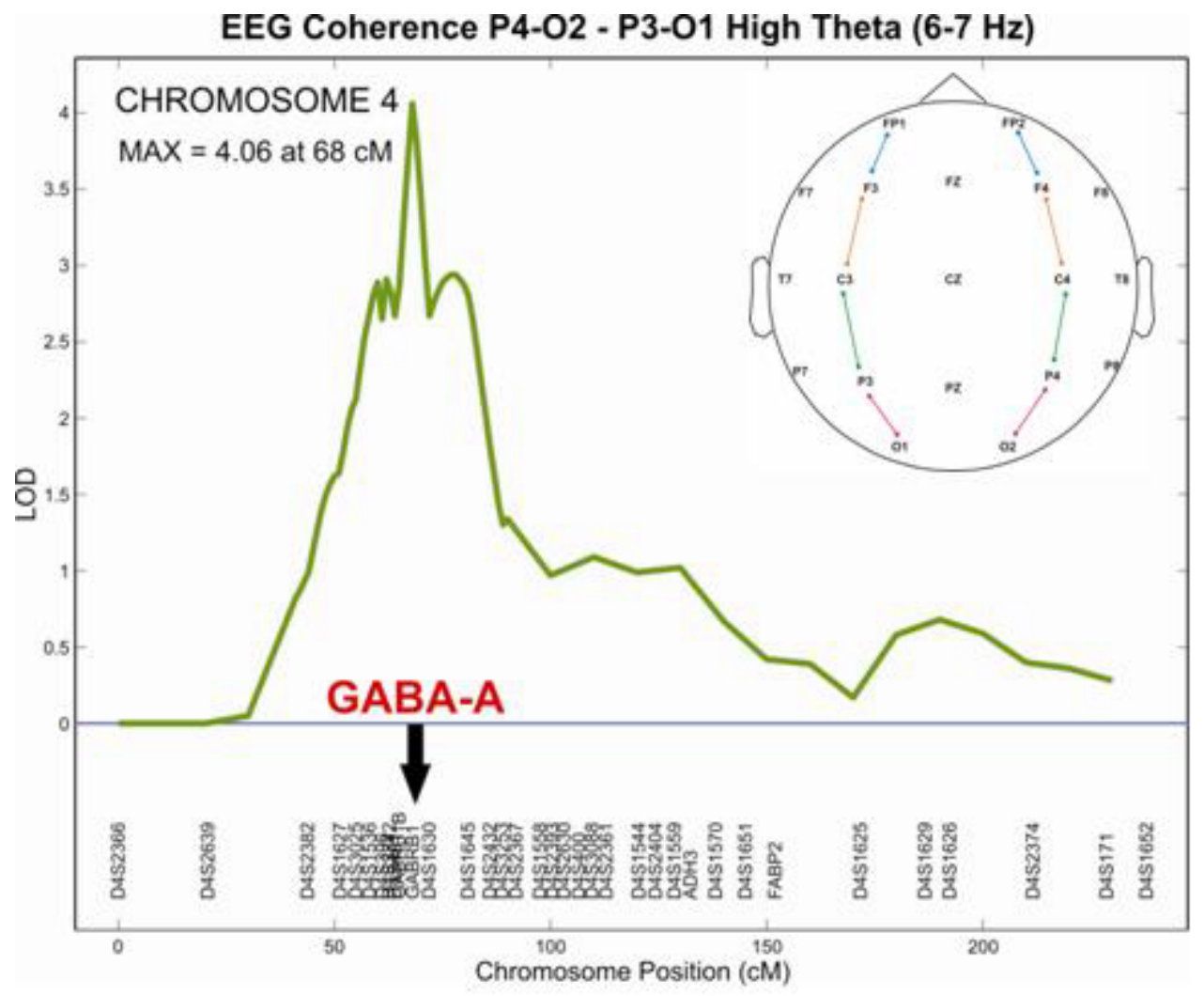

FIGURE 2. Linkage results of resting EEG of high theta band (6-7 Hz) interhemispheric coherence at parieto-occipital bipolar pairs of electrodes (P4-O2-P3-O1) on chromosome 4, indicating a significant linkage peak over the cluster of $\mathrm{GABA}_{\mathrm{A}}$ receptor genes. (N = 1312 individuals from 251 families.) Inset: head map of electrode pairs (P4-O2-P3-O1 in red).

Therefore, COGA genetic analyses were performed on the event-related oscillations (EROs) underlying the P3, namely the delta and theta EROs. Theta and delta oscillations underlying P3 are related to different cognitive functions: theta is associated with memory processes and attention, and involves fronto-limbic or cortico-hippocampal interactions, and is taken as an index of frontal processing; delta is related to signal detection and decision making, and is generated by cortico-cortical interactions and is prominent after the target stimuli.

It has recently been reported that both delta and theta EROs are reduced in alcoholics compared to controls to target stimuli during a visual oddball paradigm[52] (Fig. 3.) These findings are most significant anteriorly for theta and posteriorly for delta. These theta and delta EROs underlying P3 to targets are already reduced in adolescent offspring at risk, and are more sensitive than P3 amplitude in discriminating between high- and low-risk offspring[53] (Fig. 3).

Significant linkage and association for frontal theta oscillations and the CHRM2 gene on chromosome 7 (measured genotype and QPDT) were found; association for parietal-occipital delta EROs was also reported[36,37] (Fig. 4). These findings implicate the possible role of CHRM2 in the generation and modulation of evoked oscillations. Theta and delta EROs depend on the level of acetylcholine (muscarinic activation). M2 receptors inhibit presynaptic release of acetycholine, leading to inhibition of irrelevant networks. Muscarinic receptors influence many effects of acetylcholine in the central and peripheral nervous system, and, hence, are expected to have a direct influence on P3 generation[54]. It is 


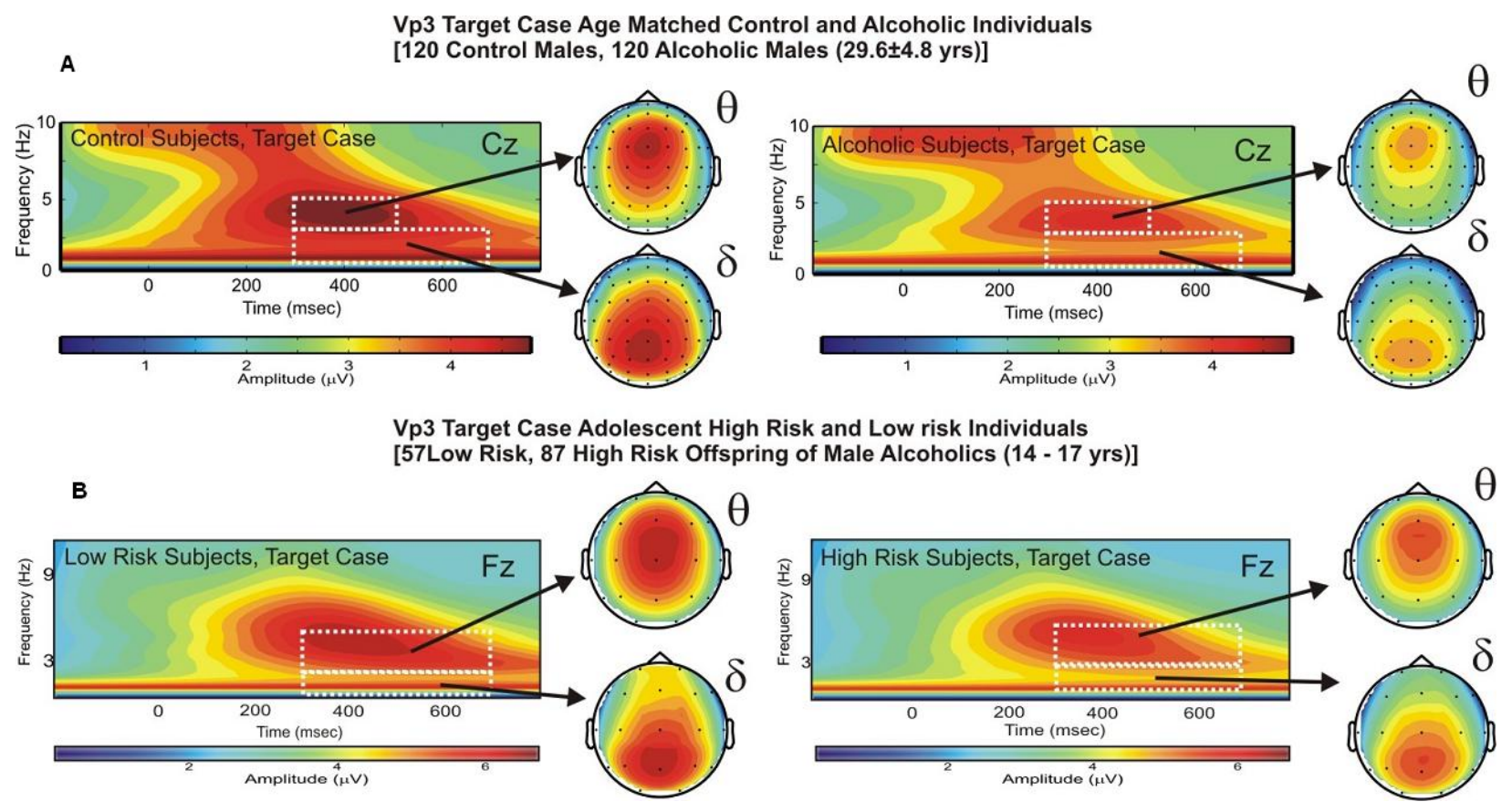

FIGURE 3. (A) S-transformed time-frequency plots for the target condition at Cz electrode (central midline) in 120 alcoholic (right panel) and 120 control (left panel) subjects, z-scored for each frequency. The head plots of the time-frequency regions of interest (TFROIs) indicate that the theta band (4-5 Hz) power during target processing (300-500 msec) has a more frontal topography while the delta band (1-3 Hz) power has a more posterior topography when P3 is maximum (350-700 msec). Note that alcoholics have weaker responses in both the theta and delta bands during P3 production to target stimuli. (B) S-transformed theta (4-7 Hz) and delta (1-3 Hz) band time-frequency plots for the target condition in visual oddball task in 87 high-risk (right panel) and 57 matched low-risk (left panel) adolescent subjects. Plots represent distributions at Fz electrode and are z-scored for each frequency. Head plots for the TFROI that extends from 300 to $700 \mathrm{msec}$ for each band (corresponds to the average temporal range of P3 wave) reveals a frontal maxima for theta band power and a parietal maxima for delta band power in adolescents.

proposed that the genetic underpinnings of evoked oscillations are likely to stem from regulatory genes that control the neurochemical processes of the brain and, therefore, influence neural function. Moreover, the cholinergic muscarinic genes have a major role in memory and cognition[55,56]. The results strongly support the role of acetylcholine in the generation of N2 (theta oscillations) and in the P3 component (delta and theta oscillations). The function of acetylcholine has been demonstrated with regard to stimulus significance[57], selective attention[58], and P3 generation[59]. Administration of cholinergic agonists and antagonists have yielded modified memory performance, and modified P3 amplitude in humans[60,61,62]. In vitro administration of moderate amounts of the muscarinic agonist carbachol in the rat hippocampus induces synchronized delta oscillations, whereas higher concentrations produced short episodes of theta oscillations, and that carbachol-induced delta rhythms were not observed concurrent with carbachol-theta[63,64].

Recent evidence from the COGA project indicates that the CHRM2 gene is not only associated with brain oscillations, but also clinical diagnosis; significant linkage and association were reported for the CHRM2 gene, and a diagnosis of alcohol dependence and depression as well as a spectrum of externalizing disorders in the COGA sample[65,66]. Thus genes important for the expression of the endophenotype (brain oscillations) help in identification of genes that increase the susceptibility for risk of alcohol dependence and related disorders. 


\section{VP3 Target 300-500 msec Theta (4-5 Hz) ERO at Cz}

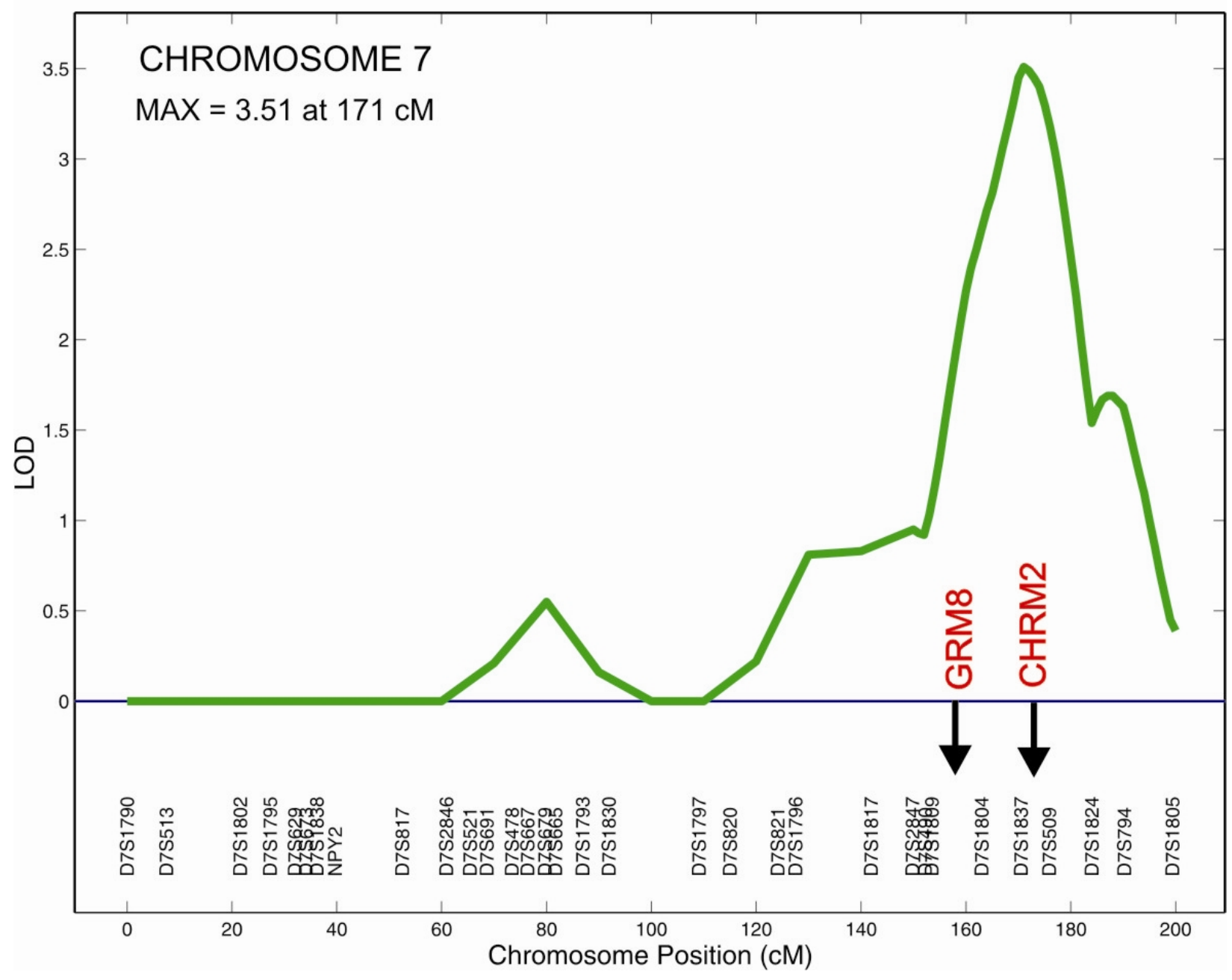

FIGURE 4. Linkage result of the target case visual central midline theta $(4-5 \mathrm{~Hz})$ band power (between $300-700$ msec, when P3 is maximum) on chromosome 7. Maximum LOD scores are situated near the location of a cholinergic muscarinic receptor gene CHRM2 and a glutamate receptor gene (GRM8). The dataset consists of 1337 individuals from 253 families.

Under the same linkage peak on chromosome 7 (Fig. 4) is a glutamate receptor (GRM8) gene; familybased association analyses of theta EROs revealed significant associations with several SNPs and theta EROs to target stimuli at frontal, central, and parietal regions[67]. An interesting finding is that several SNPs were also significant for diagnosis of alcohol dependence using ICD-10 diagnostic criteria. GRM8 modulates glutamatergic transmission in the brain by inhibiting glutamate release at the synapse. The three major neurochemical substrates contributing to theta and delta rhythms and P3 involve strong GABAergic, cholinergic, and glutamatergic system interactions[54].

\section{IMPLICATIONS: BEHAVIORAL AND CNS DISINHIBITION}

The low visual P3 amplitude is not specific to risk of alcohol dependence, but is characteristic of many disinhibitory conditions, such as substance abuse, ASP, conduct disorder, attention deficit hyperactivity disorder (ADHD)[41]. Alcohol dependence is a disorder of disinhibition characterized by disturbed impulse regulation (i.e., the inability to terminate inappropriate behavior). These traits are not unique to 
alcoholism, but are fundamental to other psychiatric disorders. Clinical manifestations of disinhibition are impulsivity, alcohol dependence, drug dependence, conduct disorder, oppositional disorder, and ADHD. There is evidence that they're a common genetic diathesis. Kendler and coworkers[6] examined the genetic and environmental influences on internalizing and externalizing disorders, and reported that the single most important factor underlying externalizing disorders (alcohol dependence, substance dependence, ASP, conduct disorder) is a common underlying genetic liability involving impulse control. Recently, it was found that alcoholics show an increased level of impulsivity, as measured by the Barratt Impulsivity Scale, and that there is a significant negative correlation between visual P3 amplitude and impulsivity score[68]. Alcoholics and highly impulsive subjects, regardless of diagnosis, showed significantly reduced activation in frontal brain regions (anterior cingulate, cingulate gyrus, medial gyrus, superior frontal gyrus) with low-resolution electromagnetic tomography (LORETA). The genetically influenced differences in susceptibility involve neural disinhibition and impulsivity, which involves frontal lobe functions that influences a range of outcomes, including externalizing and mood disorders, alcoholism, and abuse of other substances[41].

\section{CONCLUSION}

Alcohol dependence and related disorders result from a complex interaction of changing genetic and environmental liabilities across development, with greater genetic loading for early-onset disorders. The use of quantitative brain oscillations as endophenotypes provides the power to more easily localize and characterize disease susceptibility genes than diagnostic categories. The utility of electrophysiological measures as endophenotypes for the study of genetic risk of disinhibitory disorders, including alcoholism, is very promising. While the endophenotype approach is not a new idea, it is an approach whose time has come. Recent advances in SNP-chip technology in molecular genetics, as well as novel statistical genetic techniques and computational power, have made this approach very tenable in the near future. Once genes are identified, risk genotypes and haplotypes can be used in prospective studies of young individuals and can lead to prevention initiatives. These studies are currently underway in the COGA project.

\section{ACKNOWLEDGMENTS}

The Collaborative Study on the Genetics of Alcoholism (COGA), Co-Principal Investigators B. Porjesz, V. Hesselbrock, H. Edenberg, L. Bierut, includes nine different centers where data collection, analysis, and storage take place. The nine sites and Principal Investigators and Co-Investigators are University of Connecticut (V. Hesselbrock), Indiana University (H.J. Edenberg, J. Nurnberger, Jr., P.M. Conneally, T. Foroud), University of Iowa (S. Kuperman, R. Crowe), SUNY Downstate (B. Porjesz), Washington University in St. Louis (L. Bierut, A. Goate, J. Rice), University of California at San Diego (M. Schuckit), Howard University (R. Taylor), Rutgers University (J. Tischfield), Southwest Foundation (L. Almasy). Zhaoxia Ren serves as the NIAAA Staff Collaborator. This national collaborative study is supported by the NIH Grant U10AA008401 from the National Institute on Alcohol Abuse and Alcoholism (NIAAA) and the National Institute on Drug Abuse (NIDA). In memory of Henri Begleiter and Theodore Reich, Principal and Co-Principal Investigators of COGA since its inception; we are indebted to their leadership in the establishment and nurturing of COGA, and acknowledge with great admiration their seminal scientific contributions to the field.

The authors are grateful to the valuable technical assistance of Kevin Jones, Andrew Chen, Chella Kamarajan, Arthur Stimus, and Carlene Haynes. 


\section{REFERENCES}

1. $\quad$ Tsuang, M.T. and Faraone, S.V. (2000) The frustrating search for schizophrenia genes. Am. J. Med. Genet. 97, 13.

2. Gottesman, I.I. and Gould, T.D. (2003) The endophenotype concept in psychiatry: etymology and strategic intentions. Am. J. Psychiatry 160, 636-645.

3. Gottesman, I. and Shields, J. (1972) Schizophrenia and Genetics: A Twin Study Vantage Point. Academic Press, New York.

4. Gottesman, I.I. and Shields, J. (1973) Genetic theorizing and schizophrenia. Br. J. Psychiatry 122, 15-30.

5. Almasy, L. (2003) Quantitative risk factors as indices of alcoholism susceptibility. Ann. Med. 35, 337-343.

6. Kendler, K.S., Prescott, C.A., Myers, J., and Neale, M.C. (2003) The structure of genetic and environmental risk factors for common psychiatric and substance use disorders in men and women. Arch. Gen. Psychiatry 60, 929937.

7. von Stein, A. and Sarnthein, J. (2000) Different frequencies for different scales of cortical integration: from local gamma to long range alpha/theta synchronization. Int. J. Psychophysiol. 38, 301-313.

8. van Beijsterveldt, C.E., Molenaar, P.C., de Geus, E.J., and Boomsma, D.I. (1996) Heritability of human brain functioning as assessed by electroencephalography. Am. J. Hum. Genet. 58, 562-573.

9. $\quad$ Propping, P., Kruger, J., and Mark, N. (1981) Genetic disposition to alcoholism. An EEG study in alcoholics and their relatives. Hum. Genet. 59, 51-59.

10. Bauer, L.O. (2001) Predicting relapse to alcohol and drug abuse via quantitative electroencephalography. Neuropsychopharmacology 25, 332-340.

11. Costa, L. and Bauer, L. (1997) Quantitative electroencephalographic differences associated with alcohol, cocaine, heroin and dual-substance dependence. Drug Alcohol Depend. 46, 87-93.

12. Winterer, G., Kloppel, B., Heinz, A., Ziller, M., Dufeu, P., Schmidt, L.G., and Herrmann, W.M. (1998) Quantitative EEG (QEEG) predicts relapse in patients with chronic alcoholism and points to a frontally pronounced cerebral disturbance. Psychiatry Res. 78, 101-113.

13. Rangaswamy, M., Porjesz, B., Chorlian, D.B., Wang, K., Jones, K.A., Bauer, L.O., Rohrbaugh, J., O'Connor, S.J., Kuperman, S., Reich, T., and Begleiter, H. (2002) Beta power in the EEG of alcoholics. Biol. Psychiatry 52, 831842.

14. Gabrielli, W.F., Mednick, S.A., Volavka, J., Pollock, V.E., Schulsinger, F., and Itil, T.M. (1982) Electroencephalograms in children of alcoholic fathers. Psychophysiology 19, 404-407.

15. Finn, P.R. and Justus, A. (1999) Reduced EEG alpha power in the male and female offspring of alcoholics. Alcohol Clin. Exp. Res. 23, 256-262.

16. Rangaswamy, M., Porjesz, B., Chorlian, D.B., Wang, K., Jones, K.A., Kuperman, S., Rohrbaugh, J., O'Connor, S.J., Bauer, L.O., Reich, T., and Begleiter, H. (2004) Resting EEG in offspring of male alcoholics: beta frequencies. Int. J. Psychophysiol. 51, 239-251.

17. Bauer, L.O. and Hesselbrock, V.M. (1993) EEG, autonomic and subjective correlates of the risk for alcoholism. $J$. Stud. Alcohol 54(5), 577-589.

18. Porjesz, B., Almasy, L., Edenberg, H.J., Wang, K., Chorlian, D.B., Foroud, T., Goate, A., Rice, J., O'Connor, S.J., Rohrbaugh, J., Kuperman, S., Bauer, L.O., Crowe, R., Schuckit, M., Hesselbrock, V., Conneally, P.M., Tischfield, J.A., Li, T.K., Reich, T., and Begleiter, H. (2002) Linkage disequilibrium between the beta frequency of the human EEG and a GABAA receptor gene locus. Proc. Natl. Acad. Sci. U. S. A. 99, 3729-3733.

19. Edenberg, H.J., Dick, D.M., Xuei, X., Tian, H., Almasy, L., Bauer, L.O., Crowe, R., Goate, A., Hesselbrock, V., Jones, K.A., Kwon, J., Li, T.K., Nurnberger, J.I., Jr., O'Connor, S.J., Reich, T., Rice, J., Schuckit, M., Porjesz, B., Foroud, T., and Begleiter, H. (2004) Variations in GABRA2, encoding the a2 subunit of the GABA-A receptor are associated with alcohol dependence and with brain oscillations. Am. J. Hum. Genet. 74, 705-714.

20. Agrawal, A., Edenberg, H.J., Foroud, T., Bierut, L., Dunne, G., Hinrichs, A.L., Nurnberger, J.I., Jr., Crowe, R., Kuperman, S., Schuckit, M., Begleiter, H., Porjesz, B., and Dick, D.M. (2006) Association of GABRA2 with drug dependence in the collaborative study of the genetics of alcoholism sample. Behav. Genet. 36(5), 640-650.

21. Dick, D.M., Agrawal, A., Schuckit, M., Bierut, L., Hinrichs, A.L., Cloninger, C.R., Fox, L., Mullaney, J., Hesselbrock, V., Nurnberger, J.I., Jr., Almasy, L., Foroud, T., Porjesz, B., Edenberg, H.J., and Begleiter, H. (2006) Marital status, alcohol dependence, and GABRA2: evidence for gene-environment correlation and interaction. J. Stud. Alcohol 67, 185-194.

22. Dick, D.M., Bierut, L., Hinrichs, A.L., Fox, L., Bucholz, K.K., Kramer, J.R., Kuperman, S., Hesselbrock, V., Schuckit, M., Almasy, L., Tischfield, J.A., Porjesz, B., Begleiter, H., Nurnberger, J.I., Jr., Xuei, X., Edenberg, H.J., and Foroud, T. (2006) The role of GABRA2 in risk for conduct disorder and alcohol and drug dependence across developmental stages. Behav. Genet. 36, 577-590.

23. Covault, J., Gelernter, J., Hesselbrock, V., Nellissery, M., and Kranzler, H.R. (2004) Allelic and haplotypic association of GABRA2 with alcohol dependence. Am. J. Med. Genet. B Neuropsychiatr. Genet. 129B, 104-109.

24. Lappalainen, J., Krupitsky, E., Remizov, M., Pchelina, S., Taraskina, A., Zvartau, E., Somberg, L.K., Covault, J., Kranzler, H.R., Krystal, J., and Gelernter, J. (2005) Association between alcoholism and gamma-amino butyric acid alpha2 receptor subtype in a Russian population. Alcohol. Clin. Exp. Res. 29, 493-498. 
25. Fehr, C., Sander, T., Tadic, A., Lenzen, K.P., Anghelescu, I., Klawe, C., Dahmen, N., Schmidt, L.G., and Szegedi, A. (2006) Confirmation of association of the GABRA2 gene with alcohol dependence by subtype-specific analysis. Psychiatr. Genet. 16, 9-17.

26. Soyka, M. (2007) Replication of GABRA2 with alcohol dependence. J. Psychiatr. Res. Epub ahead of print.

27. Whittington, M.A., Traub, R.D., Kopell, N., Ermentrout, B., and Buhl, E.H. (2000) Inhibition-based rhythms: experimental and mathematical observations on network dynamics. Int. J. Psychophysiol. 38, 315-336.

28. Begleiter, H. and Porjesz, B. (1999) What is inherited in the predisposition toward alcoholism? A proposed model. Alcohol. Clin. Exp. Res. 23, 1125-1135.

29. Abi-Dargham, A., Krystal, J.H., Anjilvel, S., Scanley, B.E., Zoghbi, S., Baldwin, R.M., Rajeevan, N., Ellis, S., Petrakis, I.L., Seibyl, J.P., Charney, D.S., Laruelle, M., and Innis, R.B. (1998) Alterations of benzodiazepine receptors in type II alcoholic subjects measured with SPECT and [123I]iomazenil. Am. J. Psychiatry 155, 15501555.

30. Lingford-Hughes, A.R., Acton, P.D., Gacinovic, S., Suckling, J., Busatto, G.F., Boddington, S.J., Bullmore, E., Woodruff, P.W., Costa, D.C., Pilowsky, L.S., Ell, P.J., Marshall, E.J., and Kerwin, R.W. (1998) Reduced levels of GABA-benzodiazepine receptor in alcohol dependency in the absence of grey matter atrophy. Br. J. Psychiatry 173, 116-122.

31. Krystal, J.H., Staley, J., Mason, G., Petrakis, I.L., Kaufman, J., Harris, R.A., Gelernter, J., and Lappalainen, J. (2006) Gamma-aminobutyric acid type A receptors and alcoholism: intoxication, dependence, vulnerability, and treatment. Arch. Gen. Psychiatry 63(9), 957-968.

Volkow, N.D., Wang, G.J., Begleiter, H., Hitzemann, R., Pappas, N., Burr, G., Pascani, K., Wong, C., Fowler, J.S., and Wolf, A.P. (1995) Regional brain metabolic response to lorazepam in subjects at risk for alcoholism. Alcohol. Clin. Exp. Res. 19, 510-516.

33. Sarnthein, J., Morel, A., von Stein, A., and Jeanmonod, D. (2005) Thalamocortical theta coherence in neurological patients at rest and during a working memory task. Int. J. Psychophysiol. 57(2), 87-96.

34. Rangaswamy, M., Chorlian, D.B., Tang, Y., and Porjesz. B. (2007) EEG Theta Coherence in Alcoholics, in preparation.

35. Rangaswamy, M., Chorlian, D.B., Tang, Y., Edenberg, H.J., Foroud, T., Goate, A., Dick, D., Hesselbrock, V., Bierut, L., and and Porjesz, B. (2007) EEG Theta Coherence: Linkage and Association between High Theta EEG Coherence and GABRA2 and CHRM2 Receptor Genes, in preparation.

36. Jones, K.A., Porjesz, B., Almasy, L., Bierut, L., Goate, A., Wang, J.C., Dick, D.M., Hinrichs, A., Kwon, J., Rice, J.P., Rohrbaugh, J., Stock, H., Wu, W., Bauer, L.O., Chorlian, D.B., Crowe, R.R., Edenberg, H.J., Foroud, T., Hesselbrock, V., Kuperman, S., Nurnberger, J., Jr., O'Connor, S.J., Schuckit, M., Stimus, A.T., Tischfield, J.A., Reich, T., and Begleiter, H. (2004) Linkage and linkage disequilibrium of evoked EEG oscillations with CHRM2 receptor gene polymorphisms: implications for human brain dynamics and cognition. Int. J. Psychophysiol. 53, 7590.

37. Jones, K.A., Porjesz, B., Almasy, L., Bierut, L., Dick, D., Goate, A., Hinrichs, A., Rice, P.J., Wang, C.J., Bauer, L.O., Crowe, R., Foroud, T., Hesselbrock, V., Kuperman, S., Nurnberger, J., Jr., O'Connor, S.J., Rohrbaugh, J., Schuckit, M.A., Tischfield, J., Edenberg, H.J., and Begleiter, H. (2006) A cholinergic receptor gene (CHRM2) affects eventrelated oscillations. Behav. Genet. 36(5), 627-639.

38. Seeger, T., Fedorova, I., Zheng, F., Miyakawa, T., Koustova, E., Gomeza, J., Basile, A.S., Alzheimer, C., and Wess, J. (2004) M2 muscarinic acetylcholine receptor knock-out mice show deficits in behavioral flexibility, working memory, and hippocampal plasticity. J. Neurosci. 24(45), 10117-10127.

39. Apergis-Schoute, J., Pinto, A., and Pare, D. (2007) Muscarinic control of long-range GABAergic inhibition within the rhinal cortices. J. Neurosci. 27(15), 4061-4071.

40. Begleiter, H., Porjesz, B., Bihari, B., and Kissin, B. (1984) Event-related brain potentials in boys at risk for alcoholism. Science 225, 1493-1496.

41. Porjesz, B., Rangaswamy, M., Kamarajan, C., Jones, K., Padmanabhapillai, A., and Begleiter, H. (2005) The utility of neurophysiological markers in the study of alcoholism. Clin. Neurophysiol. 116, 993-1018. Halgren, E., Squires, N.K., Wilson, C.L., Rohrbaugh, J.W., Babb, T.L., and Crandall, P.H. (1980) Endogenous potentials generated in the human hippocampal formation and amygdala by infrequent events. Science 210, 803-805.

43. Menon, V., Ford, J.M., Lim, K.O., Glover, G.H., and Pfefferbaum, A. (1997) Combined event-related fMRI and EEG evidence for temporal-parietal cortex activation during target detection. Neuroreport 8, 3029-3037.

44. Kiehl, K.A. and Liddle, P.F. (2001) An event-related functional magnetic resonance imaging study of an auditory oddball task in schizophrenia. Schizophr. Res. 48, 159-171.

45.

Ardekani, B.A., Choi, S.J., Hossein-Zadeh, G.A., Porjesz, B., Tanabe, J.L., Lim, K.O., Bilder, R., Helpern, J.A., and Begleiter, H. (2002) Functional magnetic resonance imaging of the brain activity in the visual oddball task. Cogn. Brain Res. 14, 347-356.

46. Yordanova, J. and Kolev, V. (1996) Brain theta response predicts P300 latency in children. Neuroreport 8, 277280.

47. Basar, E., Basar-Eroglu, C., Karakas, S., and Schurmann, M. (1999) Are cognitive processes manifested in eventrelated gamma, alpha, theta and delta oscillations in the EEG? Neurosci. Lett. 259, 165-168.

48. Basar-Eroglu, C., Basar, E., Demiralp, T., and Schurmann, M. (1992) P300 response: possible psychophysiological 
correlates in delta and theta frequency channels. A review. Int. J. Psychophysiol. 13, 161-179.

49. Karakas, S., Erzengin, O.U., and Basar, E. (2000) The genesis of human event-related responses explained through the theory of oscillatory neural assemblies. Neurosci. Lett. 285, 45-48.

50. Karakas, S., Erzengin, O.U., and Basar, E. (2000) A new strategy involving multiple cognitive paradigms demonstrates that ERP components are determined by the superposition of oscillatory responses. Clin. Neurophysiol. 111, 1719-1732.

51. Anokhin, A.P., van Baal, G.C., van Beijsterveldt, C.E., de Geus, E.J., Grant, J., and Boomsma, D.I. (2001) Genetic correlation between the P300 event-related brain potential and the EEG power spectrum. Behav. Genet. 31, 545554.

52. Jones, K.A., Porjesz, B., Rangaswamy, M., Kamarajan, C., Padmanabhapillai, A., Chorlian, D., Stimus, A., and Begleiter, H. (2006) S-transform time-frequency analysis of event-related oscillations reveals multiple P300 source deficits in individuals diagnosed with alcoholism. Clin. Neurophysiol. 117, 2128-2143.

53. Rangaswamy, M., Jones, K.A., Porjesz, B., Chorlian, D.B., Padmanabhapillai, A., Kamarajan, C., Kuperman, S., Rohrbaugh, J., O'Connor, S.J., Bauer, L.O., Schuckit, M.A., and Begleiter, H. (2007) Delta and theta oscillations as risk markers in adolescent offspring of alcoholics. Int. J. Psychophysiol. 63(1), 3-15.

54. Frodl-Bauch, T., Bottlender, R., and Hegerl, U. (1999) Neurochemical substrates and neuroanatomical generators of the event-related P300. Neuropsychobiology 40, 86-94.

55. Calabresi, P., Centonze, D., Gubellini, P., Pisani, A., and Bernardi, G. (1998) Blockade of M2-like muscarinic receptors enhances long-term potentiation at corticostriatal synapses. Eur. J. Neurosci. 10, 3020-3023.

56. Comings, D.E., Wu, S., Rostamkhani, M., McGue, M., Lacono, W.G., Cheng, L.S., and MacMurray, J.P. (2003) Role of the cholinergic muscarinic 2 receptor (CHRM2) gene in cognition. Mol. Psychiatry 8, 10-11.

57. Perry, E., Walker, M., Grace, J., and Perry, R. (1999) Acetylcholine in mind: a neurotransmitter correlate of consciousness? Trends Neurosci. 22, 273-280.

58. Mitrofanis, J. and Guillery, R.W. (1993) New views of the thalamic reticular nucleus in the adult and the developing brain. Trends Neurosci. 16, 240-245.

59. Callaway, E. (1983) The pharmacology of human information processing. Psychopharmacologia 20, 359-370.

60. Dierks, T., Frolich, L., Ihl, R., and Maurer, K. (1994) Event-related potentials and psychopharmacology. Cholinergic modulation of P300. Pharmacopsychiatry 27, 72-74.

61. Hammond, E.J., Meador, K.J., Aung-Din, R., and Wilder, B.J. (1987) Cholinergic modulation of human P3 eventrelated potentials. Neurology 37, 346-350.

62. Potter, D.D., Pickles, C.D., Roberts, R.C., and Rugg, M.D. (2000) Scopolamine impairs memory performance and reduces frontal but not parietal visual P3 amplitude. Biol. Psychol. 52, 37-52.

63. Fellous, J.M. and Sejnowski, T.J. (2000) Cholinergic induction of oscillations in the hippocampal slice in the slow (0.5-2 Hz), theta (5-12 Hz), and gamma (35-70 Hz) bands. Hippocampus 10, 187-197.

64. Tiesinga, P.H., Fellous, J.M., Jose, J.V., and Sejnowski, T.J. (2001) Computational model of carbachol-induced delta, theta, and gamma oscillations in the hippocampus. Hippocampus 11, 251-274.

65. Wang, J.C., Hinrichs, A.L., Stock, H., Budde, J., Allen, R., Bertelsen, S., Kwon, J.M., Wu, W., Dick, D.M., Rice, J., Jones, K., Nurnberger, J.I., Jr., Tischfield, J., Porjesz, B., Edenberg, H.J., Hesselbrock, V., Crowe, R., Schuckit, M., Begleiter, H., Reich, T., Goate, A.M., and Bierut, L.J. (2004) Evidence of common and specific genetic effects: association of the muscarinic acetylcholine receptor M2 (CHRM2) gene with alcohol dependence and major depressive syndrome. Hum. Mol. Genet. 13, 1903-1911.

66. Dick, D.M., Aliev, F., Wang, J.C., Grucza, R.A., Schuckit, M., Kuperman, S., Kramer, J., Hinrichs, A., Bertelsen, S., Budde, J.P., Hesselbrock, V., Porjesz, B., Edenberg, H., Bierut, L.J., and Goate, A. (2007) Using dimensional models of externalizing psychopathology to aid in gene identification. Arch. Gen. Psychiatry, under re-review.

67. Chen, A.C.H., Tang, Y., Rangaswamy, M., Wang, J., Almasy, L., Edenberg, H.J., Hesselbrock, V., Nurnberger, J., Jr., Kuperman, S., O'Connor, S.J., Schuckit, M.A., Rohrbaugh, J., Bauer, L.O., Foroud, T., Tischfield, J., Rice, J.P., Bierut, L., Goate, A., and Porjesz, B. (2007) Association of Single Nucleotide Polymorphisms in a Glutamate Receptor Gene (GRM8) with Theta Power of Event-Related Oscillations and Alcohol Dependence, in preparation.

68. Chen, A.C.H., Porjesz, B., Rangaswamy, M., Kamarajan, C., Tang, Y., Jones, K.A., Chorlian, D.B., Stimus, A., and Begleiter, H. (2007) Reduced frontal lobe activity in subjects with high impulsivity and alcoholism. Alcohol. Clin. Exp. Res. 31(1), 156-165.

\section{This article should be cited as follows:}

Porjesz, B. and Rangaswamy, M. (2007) Neurophysiological endophenotypes, CNS disinhibition, and risk for alcohol dependence and related disorders. TheScientificWorldJOURNAL 7(S2), 131-141. DOI 10.1100/tsw.2007.203. 

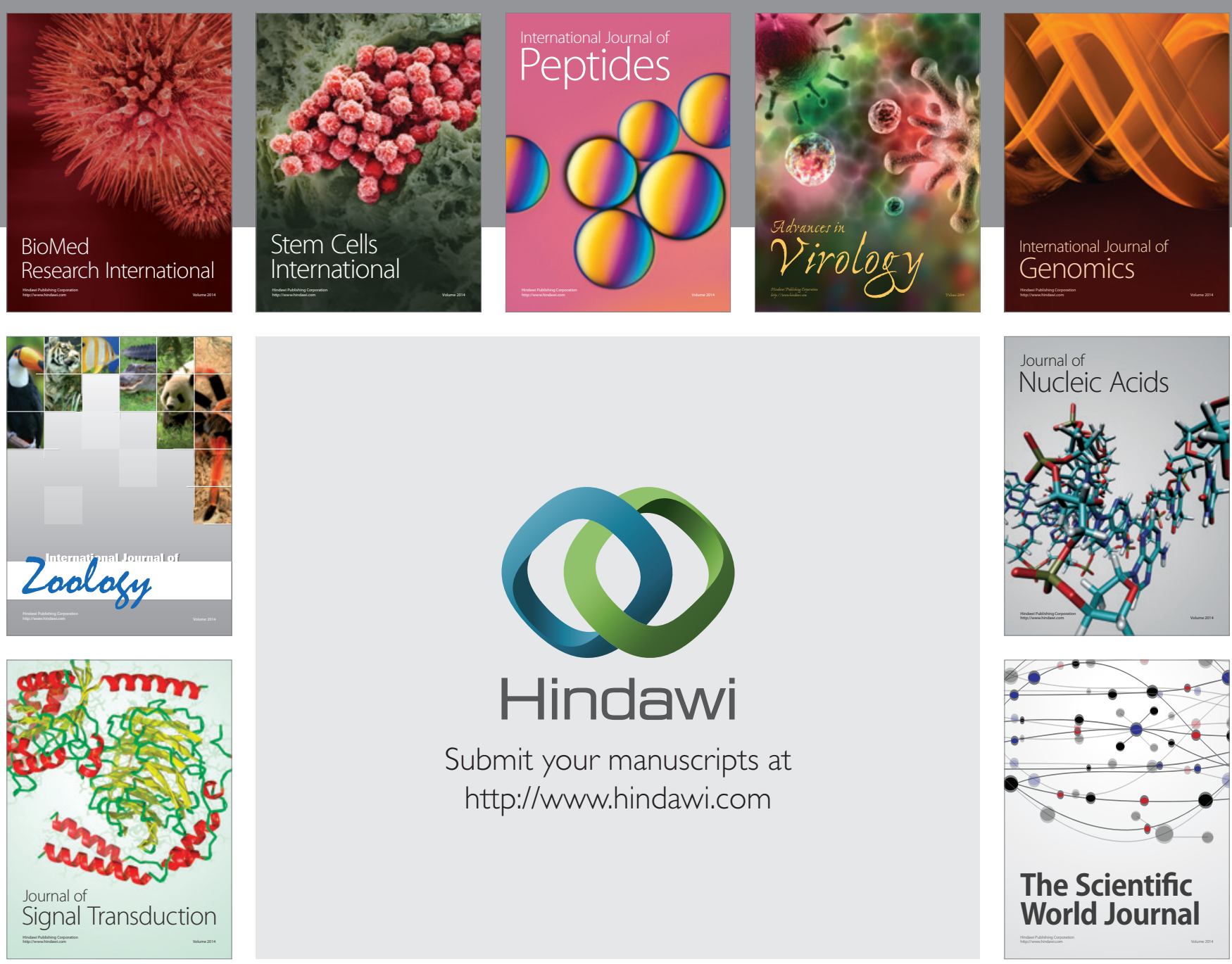

Submit your manuscripts at

http://www.hindawi.com
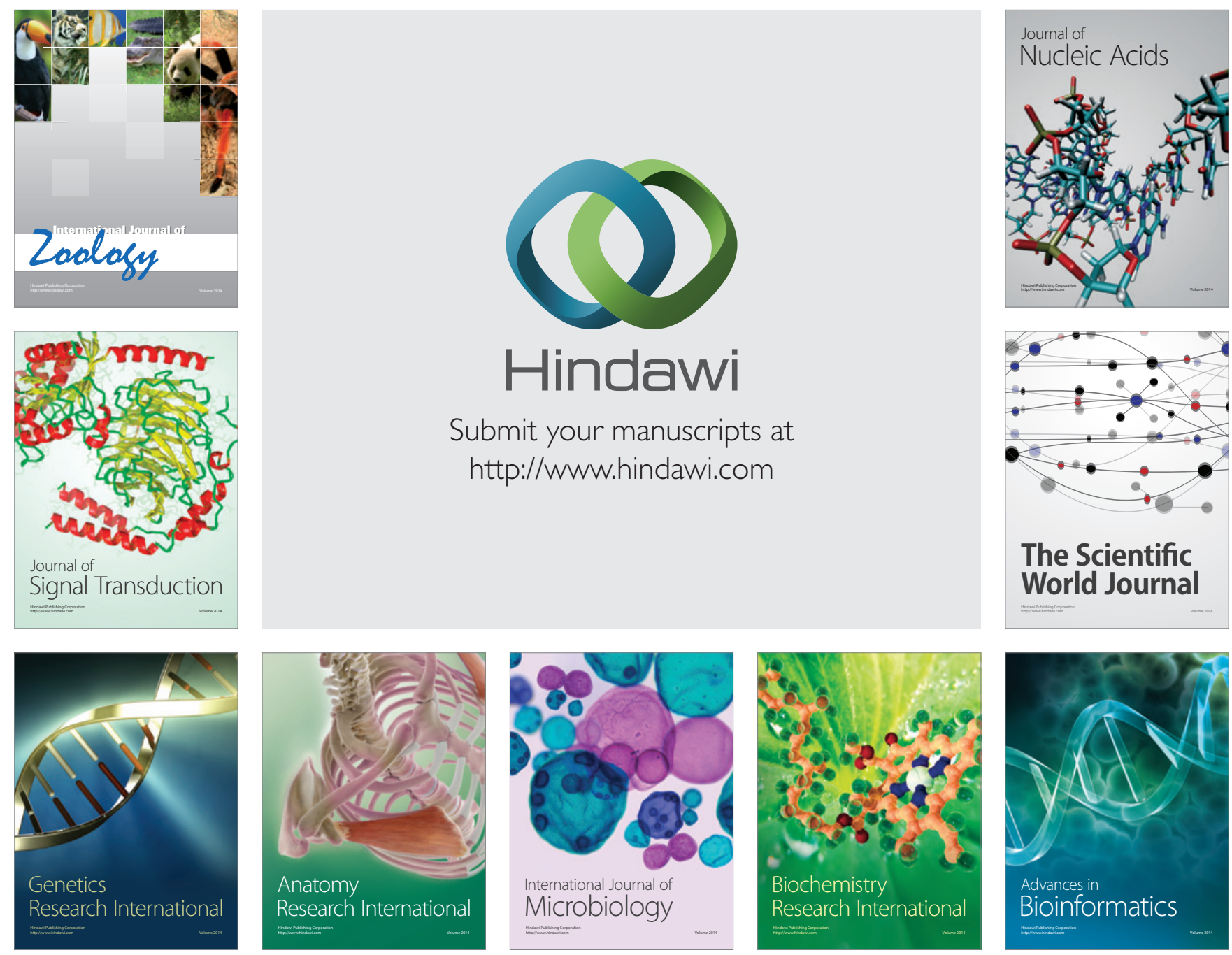

The Scientific World Journal
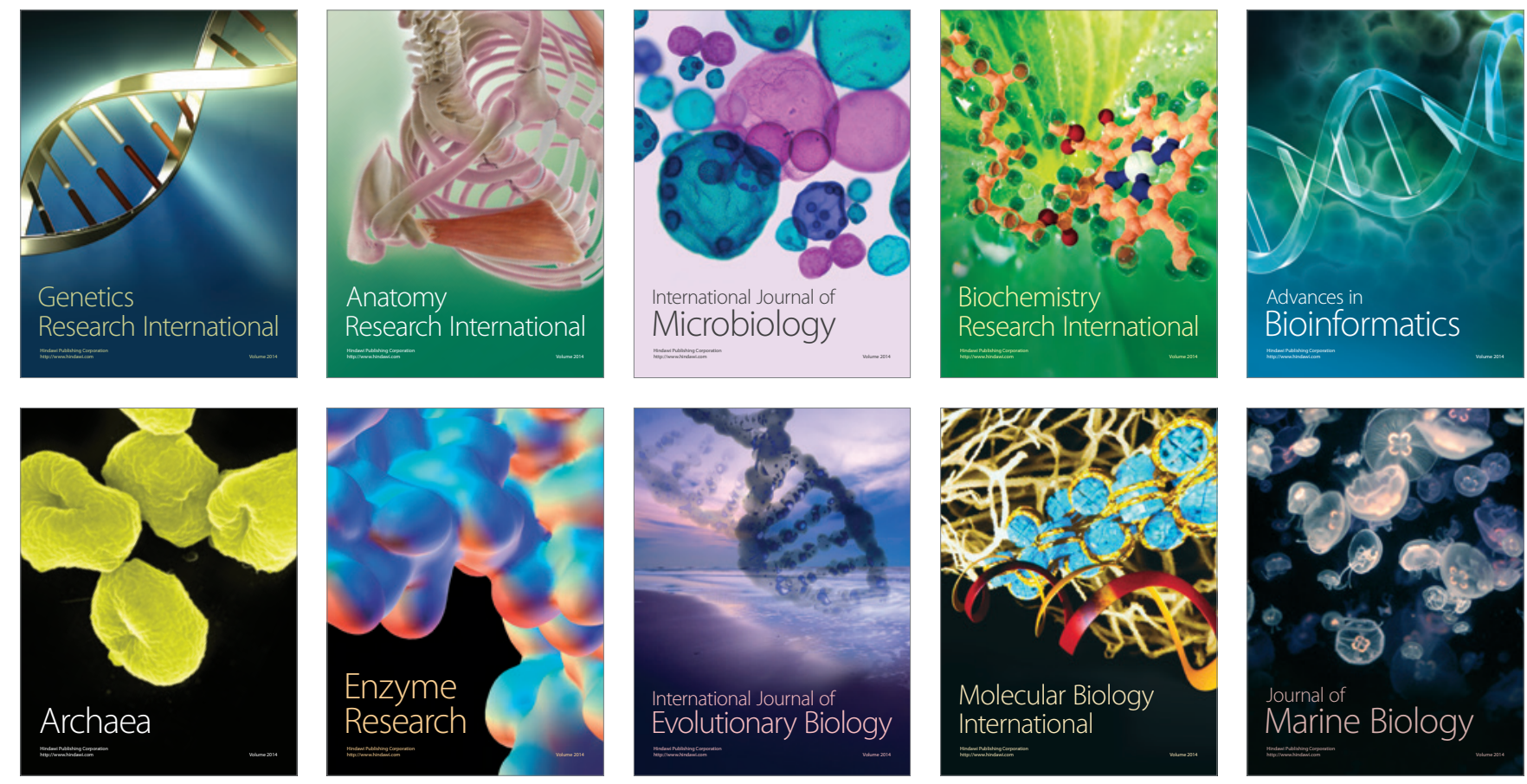